\title{
再開発ビルにおける区分所有の独立性と区分床のオープン利用 一S 市の二事業を対象としたケース・スタディー \\ INDEPENDENCE OF CONDOMINIUM OWNERSHIP AND OPEN FLOOR USE IN URBAN REDEVELOPMENT BUILDINGS \\ - A case study of 2 redevelopment projects in S City-
}

\author{
近江 隆*, 松村 崇** \\ Takashi OMI and Takashi MATSUMURA
}

\begin{abstract}
The purpose of this study is to make clear the necessary conditions for open floor use of the redevelopment building that is made by braking the force of independence of condominium ownership given guarantee with wall of partition and with access from public open spaces without traffic interruptions.

These conditions are as follows. 1) separation of ownership and use 2) two step lease 3) restrictions of the independence based on the contract 4) restrictions based on management of common use spaces 5) dependence of access from the exterior of the building
\end{abstract}

Keywords : condominium ownership, urban redevelopment, joint ownership , building management, seperation of ownership and use

区分所有， 都市再開発，共同所有，管理・運営，所有と利用の分離

\section{1. 課題と方法}

非マンション系区分所有建物の中で、通常の区分所有 ビルとは異なる系列のものとして、市街地再開発事業に よってっくりだされる区分所有建物がある。市街地再開 発事業は基本的には共有方式を目指しているが、ほとん どの事業はその中で区分所有を導入している。それは区 分所有がその本質において弱小権利の独立性を保証し、 権利行使の自由を担保するからである。しかし、区分所 有の要件である「構造上の独立性」、「利用上の独立性」 を厳格に担保するならば、多数の権利者や所有者を含む 再開発ビルは狭い空間に分割され、商業・業務空間とし ては使いにくいものとなる。オープンな厸い空間を一括 して共通のコンセプトのもとに販売に取り組む商業店舗 としては、自らの権利の保護と経営の板块みとなり、決 断を迫られる"。無隔壁型区分所有之呼ぶ空間のありか たはこうした問題に対して、区分所有法の限界性に対す る再開発事業の側からの挑戦ともみられる22。 実際の再開発事業では区分所有の「利用上の独立性」
を隔壁によって明確に区分することをせず、幾つかのシ ステムを介して、無隔壁型区分所有という区分を越えて 空間を連続させて利用する方式を成立させている。そこ に介在するシステムは、1)所有と利用の分離による制限、 2)二段階の貨貸借方式、3)契約等による制限、4)共用部 分の管理による制限、5)外部アクセスの依存等による独 立性の緩和である。これらによって区分の「利用上の独 立性」が弱体化する面もあるが、それは逆に「構造上の 独立性」の要件としての隔壁への依存を弱め、複雑に細 分化された所有形態を共通の目的に結び付ける柔軟なシ ステムを目指しているとも言えよう。

昭和58年に改正された区分所有法は団体法の性格を強 めたといわれる。集会の決議や規約での規定により通常 とは異なる権利の配分や利用状態を作り出せる。言わば、 契約当事者の一致した取り決めによって区分所有が本来 有する権利を一部制限することが可能である。区分所有 が全体から独立した財産として、その利用、収益、処分 等の自由を担保するための仕掛けが「構造上の独立性」
* 東北大学工学部建築学科 助教授 $\cdot$ 工博

** 東北大学工学部建築学科 大学院生
Assoc. Prof., Dept. of Architecture, Univ. of Tohoku, Dr. Eng. Graduate Student, Dept. of Architecture, Univ. of Tohoku, M. Eng. 
と「利用上の独立性」である。それは自由な私人の行為 が財産権を侵害しないようにするためのものである。し かし、自由な私人が契約に基づいて権利の制限を許容す る以上、物理的な独立性の要件は意義を相対的に減少さ せるものとみられる。区分所有法は当然、十全な契約の 一般的成立を前提として区分所有の独立性を考えている わけではないので、それが一般的に独立性を有するため の要件を設定しているのである。従って、これを逆に考 えれば独立性の制限を契約によって合意し、区分所有ビ ルの空間の合目的的利用のための一連のシステムを有す るものは、物理的隔壁等による独立性の担保を要しない といえるのではないか。そこで、区分床を連続的に利用 するために隔壁を伴わない区分床の所有・利用の実態と 可能性を検討することが本研究の目的である。

前報了では、市街地再開発事業によってっくりだされ た再開発ビルの中で、区分所有がどのような成立形態を とるのか、また、所有之利用の分離や隔壁の仕様によっ て本来の独立した区分所有形態とは異なる形態がどのよ うに成立してくるのかを解明してきた。本報ではそれら の変形区分所有による空間の結合によって様々な異なる 要求がどのように調整され、再開発ビルの床がオープン 利用されるかを、S市における二つの再開発事業を対象 にケース・スタディを行い、この問題の解明の采口を探 ることとした。

調查の方法 : 前報で対象とした市街地再開発事業の中 から、本論の論点に示唆的な区分所有形熊を内包する $\mathrm{S}$ 市の商業系再開発ビル 2 事例を選定し、事業関係資料、

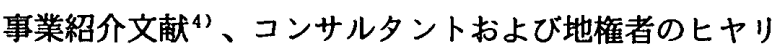
ング、建物利用実態調查、登記簿閲覧等により、(1)所有 形態の成立過程、(2)所有之利用の分離状況、(3)管理シス テムを把握した。

\section{2. 対象再開発地区の概況と区分所有の特徵}

\section{(1) $\mathrm{A}$ 再開発事業}

従前この地区は駅前地でありながら老朽化した木造家 屋や駐車場等の更地が多く、利用度の低い地区として取 り残されていたため、S市から駅前整備計画が出された ことを契機に再開発が行われた。当事業では市が作成し た基本計画に基ついて事業を進的ていくこと、全体のコ ンセプトは設計者に任せることなどが地権者の間で合意 されていたが、権利変換の手法や参加組合員の選定など、 地権者の財産や権利に関してはあくまで地権者の意見が 最倭先された。権利変換方式は全員同意による特則型、 施設建築敷地は地上権設定による区分所有で、20筆の内 1 筆は単独所有とし、地上権を設定していない。また、 取得床の所有形態は自分の勖産としての所有権を明確に したいという地権者の要望から区分所有形式をとり、全
表 1 地区の概況

\begin{tabular}{|c|c|c|}
\hline 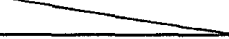 & $\mathrm{A}$ 再開発車業 & $\mathrm{B}$ 再開発事業 \\
\hline 施 行 主体 & 組 & 粗 \\
\hline 地 区 立 地 & 駅前 & 都 心 \\
\hline 地 区 性 格 & 商㸓集梢地 & 商背㷛地 \\
\hline 用 途 地 域 & 商荣地区 & 商業地 区 \\
\hline 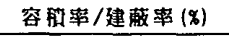 & $800 / 80$ & $650 / 90$ \\
\hline 都市計画決定 & s51 & s54 \\
\hline 宣赏了公告 & s57 & $\mathrm{s} 62$ \\
\hline 椎 利 梦 換 型 & 全员同总型 (110条) & 全只同总型 (110条) \\
\hline 地区面程 $(\mathrm{ha})$ & 0.52 & 0.90 \\
\hline 建 築 形 照 & 埋 & 一棟型（积首） \\
\hline 階数（地上/地下） & $8 / 2$ & $8 / 3$ \\
\hline 延床面糐 $\left(\mathrm{m}^{2}\right)$ & 22,695 & 30.320 \\
\hline 土地の所有形照 & 従前のまま不変 & 三篗に区分 \\
\hline 地 & 定 & 一 部設 定 \\
\hline 地锥者 土地所有者 & 15 & 6 \\
\hline (人) 借地擢者 & 2 & 17 \\
\hline 呿出者 $($ 人) & 1 & 0 \\
\hline 主な建物用途 & 商業施設 & $\begin{array}{l}\text { 酸施設、公共文化施設 } \\
\text { 地下鉄施設 }\end{array}$ \\
\hline 參加組 合 & 地梅著法人 & M不助産、S市 \\
\hline 管 & 地権者法人 & $\begin{array}{l}\text { 地梅者法人 } \\
\text { (財) S市市民文化事葷団 }\end{array}$ \\
\hline 遇 & キーテナント & $\begin{array}{l}\text { 地榷者法人 } \\
\text { (財) } \mathrm{S} \text { 市市民文化事䍵団 }\end{array}$ \\
\hline
\end{tabular}

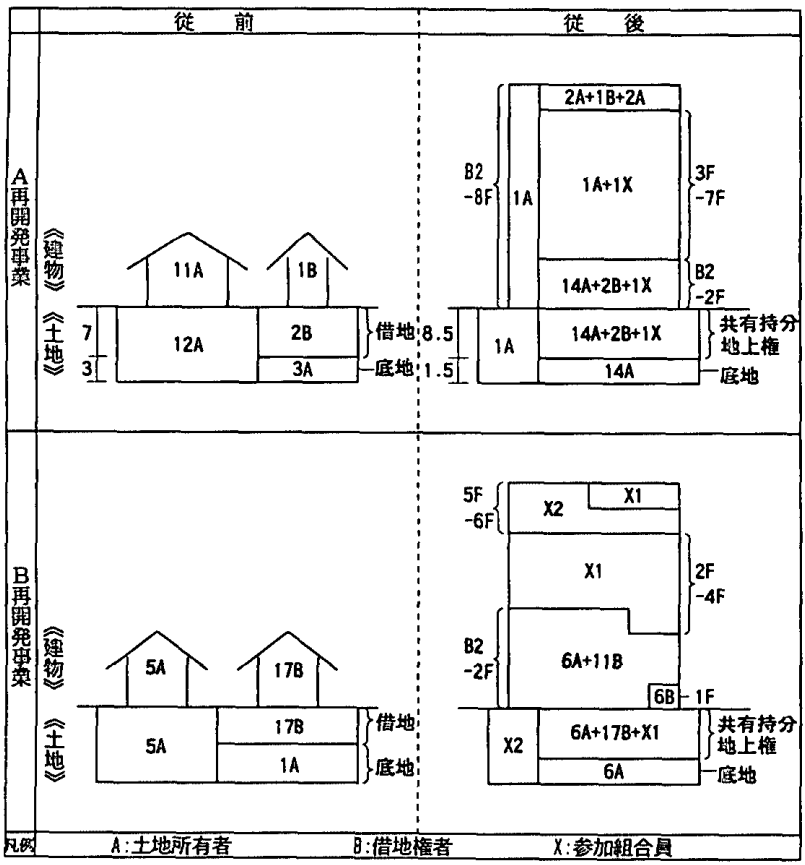

図 1 対象地区の権利変換方式 ${ }^{5)}$

ての保留床は参加組合員である地権者法人が取得してい る。地権者は 1名を除く全員が再開発組合員として事業 に参加していたが、その内の 2 名が事業の途中で脱退し、 1名は共同ビル形式をとる形で参加している。キーテナ ントは、事業当時笅しかった商調協、近代協を考慮して 地元の大型店を優先し、旧M屋の 3 店赤を統合し誘致し た。

この建物の特徵は、(1)幾つかの縦割区分所有が存在し、 あたかも 1 棟つう独立した区分所有ビルの連合体のよう な形態をとっていること、(2)単独では全く利用に向かな 
い位置・形態の保留床が存在し、 それが一体的に管理されているこ と、(3このことを可能にする所有 区分之利用区分の分離を徽底する システムを有していること等であ る。6)

(2) B 再開発事業

$\mathrm{S}$ 市の代表的な商店街に位置す るこの地区は、老朽木造家屋等に 囲まれ、他地区に比べ近代化が遅 机商業基盤の低下を招いていた。 S市はこの地区を要整備地区とし、 借地権者有志の建て替えへの前向 きな姿勢も相俟って再開発が行わ れた。権利変換計画は全員同意に よる特則型、施設建築䑤地は地上 権設定の共有だが、参加組合員で あるS市の希望で公共文化施設、

【用 途】

【所有者】

【形式決定要素】

【空間利用形式】

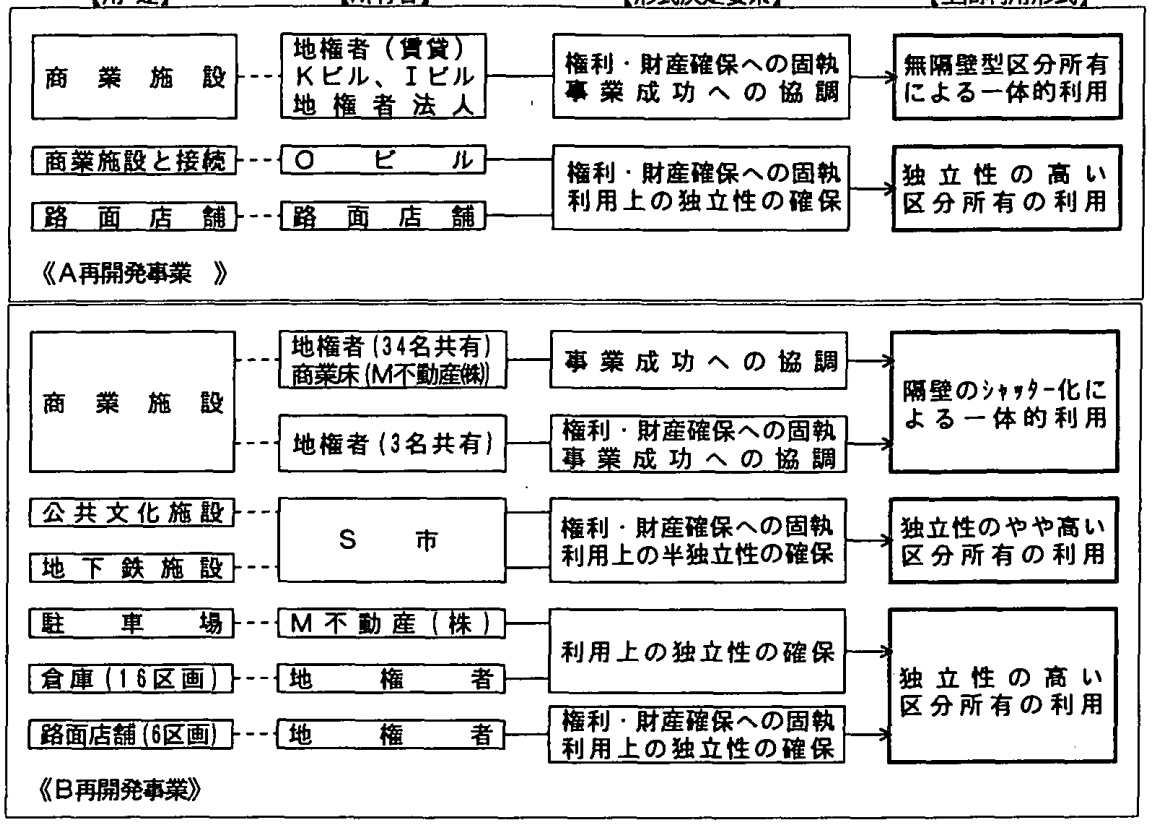

図2 区分所有形態の成立要因

地下鉄施設の用に供する敷地に関しては、S市の単独所 有の形式をとっている。休の所有形態は路面店舗之 1 階 の一部の権利床および倉庫を区分所有とし、他の権利床 は地権者が共有している。保留床には商業施設、公共文 化施設、地下鉄施設、路面店舖の梅利床部分を差し引い た部分、倉庫の 5 種類がある。前二者はそれぞれ参加組 合員であるM不動産（株）とS市が、残りの三つの部分 は一般保留床処分として、それぞれS市、路面店舗床所 有者、一部の地権者が取得している。

この事業は元々キーテナント主導型の再開発事業とし て進められたが、途中二度のキーテナントの参加消極化 により、昭和56年 6 月、地権者有志によるワーキンググ ループの指導の基に組合主導型再開発へと大きく事業方 針を変更する。この二度にわたる挫折を経験したことが、 再開発ビルの所有形態並びに管理に大きく影響している。 その結果、権利床を基本的に共有とし、商業施設の管理 を地権者法人が行うという方針ができ、参加組合員も事 業、施設のコンセプトや管理計画を決定した上で選定さ れた。この建物は言わば複合用途開発であり、商業施設、 公共施設、交通施設の異なる用途が、公共一民間、共有 一区分所有、路面店舗－建物内店舗、地上権設定一非設 定といった異なる要素を包含しながら管理されていると ころに特徵がある。

このようにA事業の権利床が全て区分所有で、B事業 は主に共有という異なる権利構造を有するにも拘わらず、 $B$ 事業も参加組合員取得休や保留床を含めると多くの区 分所有床によって建物が構成されている。そこで両事業 とも区分所有床を広くオープンな空間として利用するた めの共通の事情があり、両者の管理システムを比較する と基本的構造に類似がみられることが分かった。以下、

3. 所有之利用の分離之貨貸借方式

\section{(1) B 地区での所有之利用の分離}

区分所有床を連続させる手法として、二つの事例に共 通する方法として、枺の所有と利用の分離がある。

$\mathrm{B}$ 地区の権利变換計画には、実施計画以前の経緯を踏 まえて、「所有形態の原則的共有」と「所有と使用の分 離」 ${ }^{8)}$ という二つの原則を揭げた。そこで所有と利用の 分離がどのように実施されたかをプランで見てみよう。 図3は、この点が最も著しくみられる1F、2F、6Fの平面 図である。左側の所有区分は、A：地権者34名取得の共 有床、B：地梅者取得の区分所有床、C, D：M不動産

（株）取得床、E：S市が取得した床で、右側の斜線部 は利用区分を示している。

1FにはB1 B B6の路面店舗とB7の 3 名共有の専有床、A3 〜 A6の34名共有の尃有床及びDの駐車場がある。このう 古所有と利用の分離の対象之なっているのはB7टA6であ る。図3をみて分かるようにA3〜A6とB7は所有形態が異 なるが隔壁をシャッターにすることであたかも一体的な 空間のように利用されている。シャッターは通常、常時 開放されている。しかしB7は、一体的な利用を承認する 代わりに「所有権の保全、処分の自由、賃貸先選択の自 由」を認められている。この点では、商業施設の一体的 な管理を将来崩される可能性を内包しているといえる。

2FにはA7：34名共有床とC1，D：M不動産（株）取得 床がある。所有と利用の分離はA7とC1の一体的運営によ り起こる。しかし、1Fの 3 名共有床とC1を比べると、B 地区の運営方針に十分な理解を示して参入したM不動産 
（株）は3名共有床の様に一体的 な管理を危うくする恐れは少ない と思われる。また、6Fの公共所有 部分は壁とシャッターで区分され ているが、部屋以外の通路、ロビ 一等は常時一般開放されている。 M不動産所有のC4についても同様 である。このことは、専有部分と しての区分所有区画の中に共用的 空間を常設し、所有と利用のズレ を容認しているといえよう。

（2）A地区の所有之利用の分離 $\mathrm{A}$ 地区の所有之利用の分離の問 題を考えるには、まず再開発ビル 内の床の定義及び認識による分類 を行わねばならない。このビルの 床には三段階の意味付けが行われ ている。三段階とは

\section{1)登記 \\ 2)建物管理規約 \\ 3)利用 (運営)}

である。この三段階でビル床はそ れぞれ異なる意味付けが為され、 最終的に所有之利用の分離が生じ ている。そこで各段階の床の意味 付けの状態を平面図で比べ、A地 区の所有之利用の分離が成立する 過程を追ってみる。

まず登記であるがここでは権利 変換によって成立した所有形態が 見られる（図 4）。A地区の土地 建物は全て区分所有である。特徵 的なこととして三つの縦割型区分 所有が存在し、その内の 1 つ、I ビルが再開発ビルを二分し、その ままの状態ではキーテナントによ る一体的なビルの利用は不可能で ある。

次に建物管理規約による意味付 けである。図4の共用部分の範囲 は管理規約の中でも変更はない。 しかし、完全自己利用の○ビル以 外の二つの縦割型区分所有の縦方 向動線部分（階段）及び機械室に 使われる部分が、管理規約によっ て「共同使用部分」として設定さ れている。「共同使用部分」とは、 管理規約で「専有部分の区分所有

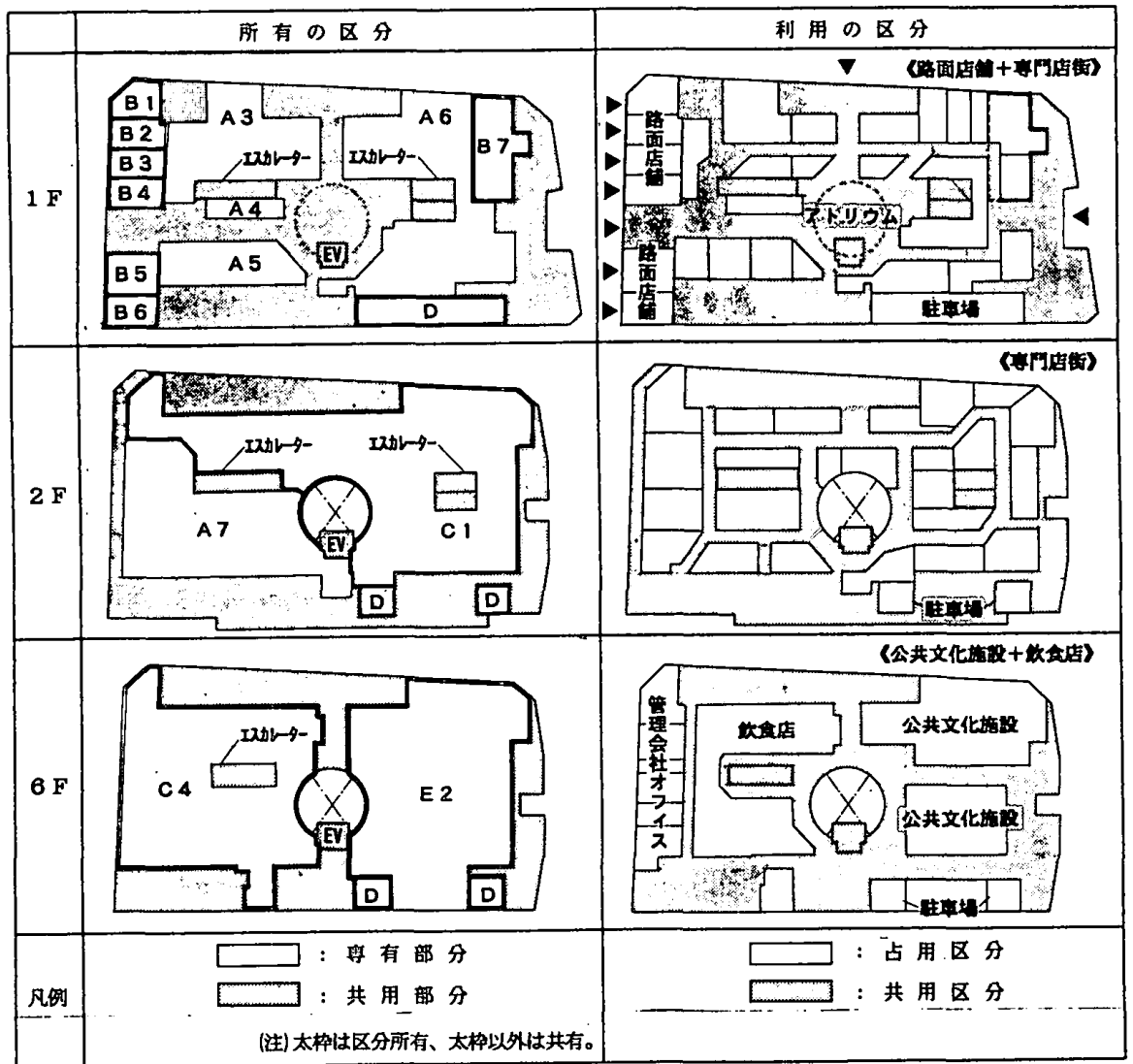

図 3 B 地区の所有之利用の区分

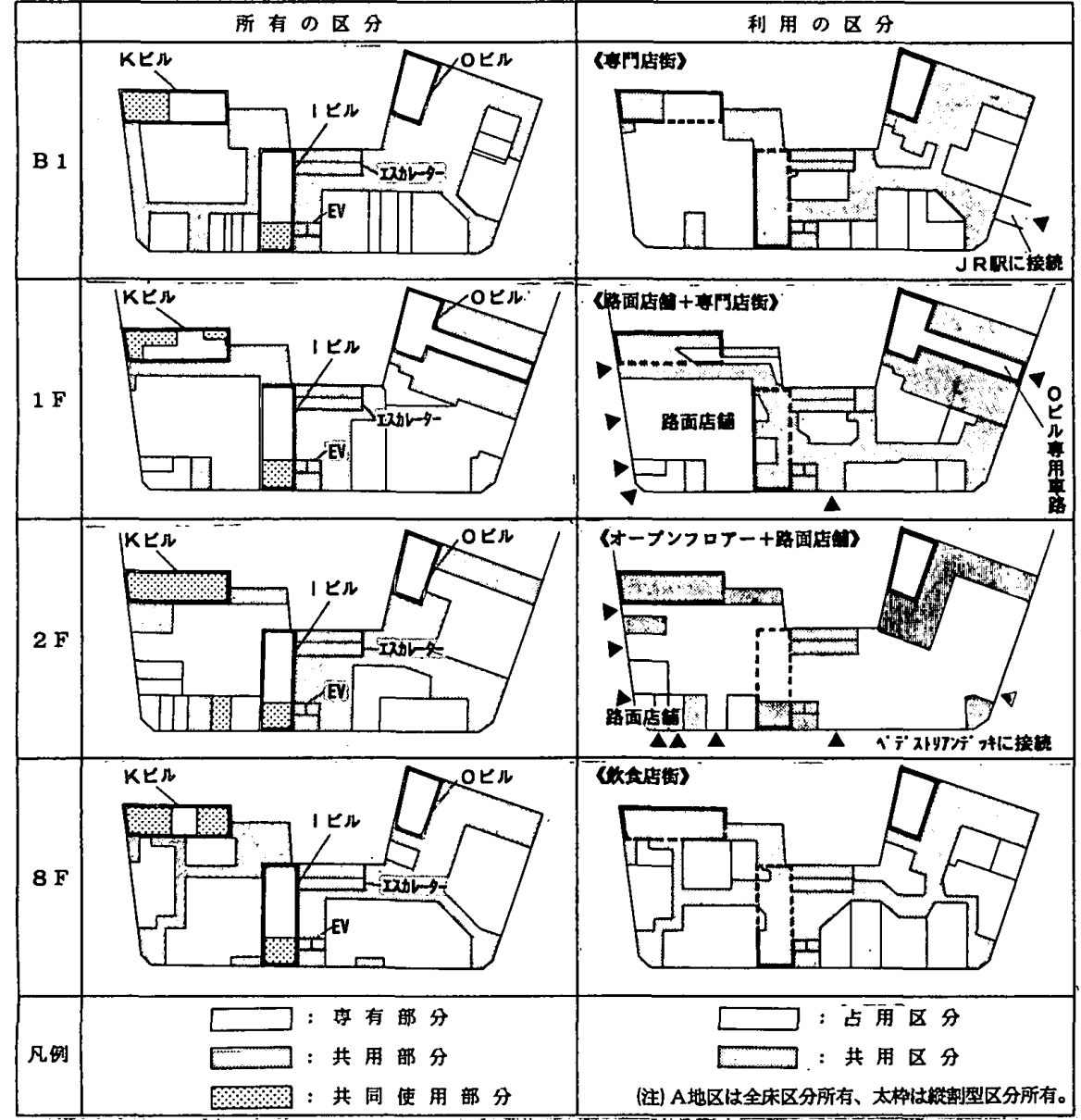

図4 A地区の所有之利用の区分 
者は、その部分を他の全ての区分所有権者に使用させね ばならない」と規定されている部分である。この規約に よる規定によって一部の専有部分に共用部分（規約共用 部分）の性格を持たせる意味付けがされたのである。こ のことによって登記上は全く独立した利用を保証されて いたKビル及び I ビルの利用目的が初めて変えられ、ま た、法律上の専有部分、共用部分を示した「登記」と実 際の利用とのズレを容認した中間的な意味付けがなされ たといえる。そしてその実現手段としての無隔壁型区分 所有への移行が暗慜のうちに前提されたのである。

しかしここで注意すべきは Kビル，I ビルの内で「共 同使用部分」に設定されなかった部分の存在、また設定 部分が階段という一般に共用性の強い部分や機械室のよ うに一見隔壁を有したままで利用しているように思える 部分があることである。これはこの二つのビルが依然、 專有的に利用される予定であることを意味し、無輞壁化 も一部分に過ぎないことを主張していると受け取れる。

最後に実際の利用である。図4 から分かるようにI ビ ルは全体的に共用部分として利用されている。もちろん 大規模な無隔壁型区分所有への移行がなされ、I ビルに よって二分されていた空間が一つになり、一体的な管理 が実現している。これがA地区の所有と利用の分離であ る。

$\mathrm{B}$ 地区の所有と利用の分離が主として異なる専有部分 を一体的に管理しているのに対して、A地区では専有部 分のみならず共用部分まで一体的に利用し、専有部分と 共用部分という所有区分とは大幅に異なる床利用の実態 が存在することが特徵である。

（3）賃貸借方式の二段階性

A地区は全所有区分が区分所有であるから、自己利用 部分を除いてすべて、個人的に賃貸借契約が成立してお り、その中の多くの部分が二段階の賃貸借関係を成立さ せている。それは「各権利者から地権者法人への賃貸」 と「地権者法人からキーテナントへの賃貸」の二段階で ある。地権者から地権者法人への專有部分の賃貸借では、 その持分割合に相当する共用部分をセットにせず、あく まで尃有部分のみの賃貸借（ネット傎貸）が行われてお り、地権者法人からキーテナントへの貨貸借では、専有 部分に共用部分を付属させて賃貸（グロス賃貸）してい る。

地権者法人がキーテナントに貨貸する部分は、「賃借 した権利床」、「自己所有床（保留床）」及び「これら の専有部分に相当する共用部分」である。この時貢貸さ れる共用部分は、地権者法人に権利床を貨貸した地梅者 の了解を得て賃貸されている。地権者之地梅者法人之の 貢貸借では、ネット貸貸の賃料をグロス貸貸の貨料に換 算する計算方式が存在する。よって地権者は専有部分だ け賃貸して共用部分に相当する賈料も受け取っている。
つまり、実質的には共用部分もあわせて貨貸しているの と同じことになる。また、個人的にキーテナントと賃貸 借契約を結んでいる権利者は、当然、ネット賃貸をして いると思われる。

B 地区の貨貸も $\mathrm{A}$ 地区同様二段階あり、「地権者、参 加組合員加ら地権者法人への㶵貸」と「地権者法人から 各テナントへの貸貸」である。B地区の賃貸借方式につ いては、共用の通路部分がエレベータ、エスカレータの 他に極僅かの部分のみであること、賃貸借に参加してい ない路面店舗は一部共用部分の共有にも属していないこ となどから、区分所有を縫うように共用通路が存在し、 その共有に属する権利者も様々であるA地区に比へ、専 有部分之共用部分の貢貸借は明解なものである。

\section{4. 管理と区分所有の独立性の制限}

A 地区と B 地区の管理システムでは、地権者法人やキ 一テナントが重要な役割をもち、彼らによる区分床の一 括借り上げにより、床の一体的運用が可能になっている。 要するに「一括借り上げされた区分床」之「他の区分床」 とでは床の性質に違いが生じるものと思われる。そこで、 区分所有が登記の要件として義務づけられている「構造 上の独立性」及び「利用上の独立性」が、管理とのかか わり合いによって、如何なる制限を加えられているのか を見てみよう。（表 $2 ， 3 ）$

まず、この「区分所有の独立性」に制限を加えるもの は、

1)契約等による制限、

2)共用部分の管理による制限、

3)外部アクセスの依存による制限

の3つに分類できる。

(1)契約等による制限

表 2 区分床の独立性の制限（A再開発事業）

\begin{tabular}{|c|c|c|c|c|c|c|c|}
\hline & $\begin{array}{l}\text { 地做者法人 } \\
\text { との䝿细借 }\end{array}$ & $\begin{array}{l}\text { キーテナント } \\
\text { との買偖 }\end{array}$ & 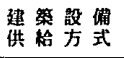 & & & \multicolumn{2}{|c|}{$\begin{array}{l}\text { 外部アクセス } \\
\text { の依存 }\end{array}$} \\
\hline 0 ヒル & - & - & - & & & 曹 & 有 \\
\hline 路面店胡 & - & - & 空珒のみ個剧 & & 再 & 再 & 有 \\
\hline I ヒル & - & $\mathrm{O}$ & セントラル & 共 & 有 & 共 & 用 $\%$ \\
\hline 再當菜 & - & 0 & セントラル & 共 & 有 & 共 & 用 \\
\hline 地嘴者法人 & - & 0 & セントラル & 共 & 有 & 共 & 用 \\
\hline Kヒル & 0 & - & セントラル & 共 & 有 & 共 & 用 $\%$ \\
\hline 需 & 0 & - & セントラル & 共 & 有 & 共 & 用 $\%$ \\
\hline
\end{tabular}

表 3 区分床の独立性の制限（B 再開発事業）

\begin{tabular}{|c|c|c|c|c|c|c|c|c|}
\hline & 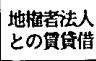 & $\begin{array}{l}\text { 共有床保全会 } \\
\text { への参相 }\end{array}$ & 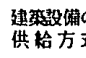 & 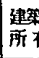 & 喵の & $\begin{array}{l}\text { 部共用部 } \\
\text { 分の宣理 }\end{array}$ & $\begin{array}{l}\text { 外部丁 } \\
\text { の俵存 }\end{array}$ & クセス \\
\hline 路面结战 & - & - & 個 & 専 & 有 & $=$ & 専 & 有 \\
\hline 地下鉄施钤 & $=$ & - & セントラ & 共 & 有 & 0 & 共 & 用 \\
\hline 公共文化施铅 & $\mathrm{O}$ & - & セントラ & 共 & 有 & 0 & 共 & 用 \\
\hline 共有床 (3名) & $0 *$ & 0 & セントラ & 共 & 有 & 0 & 共 & 用 \\
\hline 其有床 (34名) & 0 & 0 & セントラ & 共 & 有 & 0 & 共 & 用 \\
\hline M不䵢産的 & $\mathrm{O}$ & - & セントラ & 共 & 有 & 0 & 共 & 用 \\
\hline 而 & $\mathrm{O}$ & - & セントラ & 共 & 有 & 0 & 共 & 用 \\
\hline
\end{tabular}


区分所有の独立性に制限を与える契約等には、地梅者 法人及びキーテナントとの「賃貸借契約」、管理組合へ の参加に関する「覚書」、「出店管理規則」そして「共 有休保全会定款」等がある。これらの契約が重複するほ ぞ、その独立性は低くなると考えられる。具体的に制限 を受けるのは区分所有の利用目的・方法・改良・処分等. 何らかの制限を与え标ば一体的な管理に支障を来しか权 ない権利である。これら複数の制限を受けることで管理 システムが機能することになる。しかし、その契約等に は絶対的な強制力がないものもあり、将来それが一体的 な管理を崩す可能性を持っていることにも目を向けなけ ればならない。

具体的には、B地区の、地権者による「3名共有床」 が挙げられる（図3のB7）。この区分床は、地権者法人 と傎貸借契約を結んでいる他の区分所有（ここでは、広 義の区分所有を指す）とは異なり、一体的な管理を承認 する交換条件として「所有権の保全」、「処分の自由」 「賃貸先選択の自由」を保証されている。3名の共有者 は従前から不動産貨貸業を営んでいたため、一体的な管 理を認める反面、貢貸不動産としての価値だけは確保し たかった事情が同える。

(2)共用部分の管理による制限

一般に区分所有は、共用部分が多ければ多いほど、そ の管理義務により利用の独立性を薄められる。本研究で は建築設備の所有形態及び一部共用部分の有無について 調查した。建築設備に関して注目すべきなのは路面店埔 及びA地区の○ビルである。○ビルは元々事業完了後に 全ての設備を際接 Sホテル側から引いている。

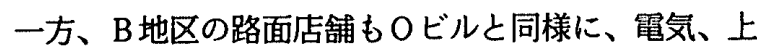
下水道等を個別に引き込んでいて、更に、建物の基幹的 構造部分（基礎、外壁、屋上、外部階段等）を全体共用 部分とし、ビル内の共用部分のほとんど（センターフォ ーラム、機械室、階段、エレベータ、エスカレータ、ト イレ等）は、路面店舗を除いた一部共用部分になってい る。これは、この路面店舗が○ビルょりも更にビル全体 の管理から分離しており、利用上の独立性が非常に高い 区分所有であるといえる。

(3)外部アクセスの依存による制限

外部アクセスの確保は、区分所有の利用の独立性にお いて非常に重要な要素之なる。外部アクセスが自分の専 有部分であるか、共用部分、一部共用部分であるかで、 再開発ビルの管理による制限を受ける度合いが異なるか らである。

路面店舗部分は、一般にそれぞれアクセスが外部に面 していて、制限は受けていない。これに対して外部アク セスを共用部分に依存する区分所有は、他の区分所有之 の利用時間の兼好合い等から、その利用に制限を受ける ことになる。例えば A地区のB 1Fは、J R 駅及び地下鉄
駅との接続通路を持つため、開放時間について協議が行 われている。また同じく $\mathrm{A}$ 地区の $8 \mathrm{~F}$ 飲食店街は、休日 の外部アクセスを共用部分であるエレベータに依存する ため、他の商業施設の開店時間からの制限は受けないで 済む。このように外部アクセスへの依存に関しては、同 じ共用部分への依存でもその共用部分の性質により制限 の受け方は異なり、一概に比べることは出来ないが、制 限の受け方の違いはその区分所有の性質の違いとして扱 えよう。

\section{5. 区分床のオープン利用と管理システム}

\section{(1) 管理システム}

A地区では、基本的にビル全体の管理を参加組合員で もある地権者法人、すなわち区分所有法の管理者が行っ ている。これが管理における責任主体であり、実際の管 理はキーテナントに業務委託され、そこが実施主体とな り、コーディネートされたコンセプトの基に一体的管理 を行っている。このような方法は、商業系再開発ビルの 管理方式としては有効なものとされる。A地区の各所有 林の利用形態としては、
1)賃貸借の無い自己利用
2)貢貸借を経た自己利用（再営業者）
3)貸貸借で第三者が利用

の3 通りが考えられる。1)は所有部分を所有者がそのま ま利用することをいう。2)は所有部分を一旦貨貸し、再 びその床を貢借して所有者が利用することをいう。この 場合、利用部分は必ずしも所有部分之一致するとは限ら ない。3)は所有部分を賃貸して第三者に利用させること をいう。

利用手段よ管理の関係をみると1)の自己利用部分と3） に該当する路面店舗は、管理において再開発ビル全体か ら分離扱いされているが、3）に該当する権利床のほとん どと增床及び共同ビルの Kビルの床は、地権者法人が一 括借り上げし、参加組合員として取得した保留床と合わ せてキーテナントに貨貸される。これらの床は、地権者 が直接キーテナントに貸貸した権利床と共にキーテナン トが一体的な管理を行っている。

ここで地権者、地権者法人、キーテナント、個々のテ ナントの間に存在する取り決めをみてみる。地権者から 地権者法人への貸貸では、両者の間に建物賃貸借契約が 結ばれ、同様に地権者法人からキーテナントへの賃貸の 際にも建物賃貸借契約が結ばれているが、同時に「業務 委託契約」も結ばれている。業務委託契約にはいくつか の種類があり、貸貸借対象部分の管理業務や共用部分付 属設備の管理業務などが地梅者法人からキーテナントに 委託されている。キーテナントはこの建物貨貸借契約と 業務委託契約に従って、賃借した床を一体的に管理して 
いる。

地権者から地権者法人への貨貸 では、地権者法人がキーテナント へ所有床を一体的に転貸すること を承諾しているが、地権者法人か らキーテナントへの賃貸では、キ 一テナントが個々のテナントに転 貸することを禁止している。さら に但し書きとして、「ケース貸し、 消化仕入方法等により部分的に使 用させ、叉は大店法の規制等によ り規制外面積の利用方法として他 人に出店させる場合はこの限りで ない。」とある。つまり個々のテ ナントの多くは床を貨借しておら ず、一般的に個々のテナントと個 別の床所有者との間で賃貸借関係 が生じることはなく、トラブルが 生じない仕組みになっている。ま た、出店の店舗は全て「出店管理規則」に従って営業を 行うことになっており、これにより商業ビルとしての統 一を成している。

B地区の管理の対象は、

1)路面店舗

2)公共文化施設を除く部分（商業施設、駐車場、 倉庫、共用部分）

3)公共文化施設

4)地下鉄施設

の 4 つの部分である。

B 地区の管理システムは A地区ほど複雑ではない。ま ず路面店舗と地下鉄施設は、ビル全体の管理から分離扱 いされている。公共文化施設は公共施設の管理に適した 法人を設立し、所有者である S 市が管理業務を委託して いる。そして、これらを除く部分の所有者は所有部分を 地権者法人でもある管理会社に賃貸し、管理会社が一体 的に管理している。区分所有法上の区分所有者の団体で ある管理組合は、管理業務の决定と監督の役割を除く業 務を区分所有法上の管理者である地権者法人に業務委託 している。

地権者及び参加組合員から地権者法人への賃貸の際に は、地権者は地権者法人が個々のテナントに転貸するこ とを承認している。よって、A地区の場合とは異なり床 所有者と個々のテナントの間で間接的に賃貸借関係が生 じている。また、同ビルでは「テナント会」を作り、貢 借した床及び公共文化施設の一体性を確保している。

B地区では権利床の多くが共有形式をとっていて、そ れを他の区分所有者の単独所有部分之一緒に一括借り上 げし、それを転貸している。しかし、このシステムでは、
共有部分の持つ「単独区分所有部分と比べて権利の保全 に関して不安定」という性質が将来問題となる。共有者 が所有権の譲渡や相続を行った際に共有部分としての一 体性が崩れてしまう可能性がある。そこで、B地区では 共有床保全の目的で同ビルの「共有床保全会」を結成し、 同会の定款で、

1)持ち分の譲渡制限

2)分割請求の禁止

3)相続の場合の代表者の選任 を定めている。

（2）地権者法人の果たす役割

A 地区、B地区の管理システムは、どちらも非常に複 雑な権利関係を抱えているが、それらをうまく調整する 工夫が為されている。両者のシステムを対比してみると 全く異なる面も有机ば、同じような方法を採用している 部分もある。その中でも注目すべきは地権者法人の存在 とその役割である。

A 地区の地権者法人は、再開発ビルの区分所有法上の 管理者であり、且つ全ての保留床を取得した参加組合員 でもある。A地区の管理で、地権者法人の果たす役割は 次のようになる（図5）。

1) 自己利用部分及び路面店舗を除く賃貸されている専 有部分と共用部分の管理をする。

2)地権者とキーテナントの間に入り所有区分の転貸を 行う。

3)キーテナントに各所有区分を賃貸すると同時に管理 業務をキーテナントに委託する。

4)所有区分の譲渡に関して先買権などの権限を持ち、 また○ビル及び自己利用部分の管理者と管理に関す 
る調整を行い、再開発ビルの一体的な管理を維持す る。

一方、B 地区の地権者法人は同じく再開発ビルの区分 所有法上の管理者であり、且つ管理実施主体でもあるが、 A地区の地権者法人之違い自ら床を所有していない。そ してB 地区の管理で地権者法人の果たす役割は次のよう になる。（図6）

1) 自己利用部分及び公共文化施設を除く専有部分と共 用部分の管理業務を管理組合より委託され行う。

2)地権者、参加組合員と個々のテナントの間に入り、 所有区分の転貸を行う。

3）公共文化施設や自己利用部分の管理者之管理に関す る調整を行い、再開発ビルの一体的な管理を維持す る。

A地区の場合は、地権者法人が管理者かつ参加組合員 として保留床を取得しているので、地権者法人にキーテ ナントとの貨貸借の調整を任せることは、地権者法人を 通して賃貸する区分所有者全員の権利の保全という面で 安心できるものだと思われる。これに対してB地区では、 M不動産（株）という地権者以外の床所有者が地権者と 同じように地権者法人を通して貢貸しているので、M不 動産（株）にとっては権利保全面で必ずしも安心できる とは言えない。このことに関してはM不動産（株）が B 地区の管理コンセプトを十分理解して参入した参加組合 員であるために問題が生じていないと思わ机る。

この様にみてみると、この二つの事例で地権者法人は、 床所有者之床利用者の貨貸借の煩わしい調整を一手に引 き受け、明解なシステムを維持するだけでなく、一旦地 権者法人に賃貸することで、利用者との賃貸借で生じた 問題が床所有者に及ばないようにする役割も果たしてい る。いわば地権者法人は市街地再開発事業で生じる微弱 な権利を保護するクッションのようなを存在であるとい える。また前章で述べた「所有と利用の分離」が、地権 者法人による一括借り上げにより実現されていることか らも、その存在の重要性が分かる。

\section{結論}

商業系再開発ビルにおける区分所有の成立形態は、同 じ区分所有法に基礎を置くとしても、マンションとは大 変異なる形態をつくりだしている。マンションが1住戸 という機能的にも独立性の高いユニットとして、尃有部 分の独立性を最大限に追及するのに対し、再開発ビルに おける商業床は路面店舗のような区分床の独立性を強く 主張し、マンションと同列の形態をなすものもある一方、 全く逆に区分床の独立性を区分所有という形式を法的に 充たす限界まで、その独立性を弱めようとする形態もあ る。マンションが全体の建物を壁で分割し区分の独立性
をつくりだすのに対し、後者は物理的隔壁を取り払い平 面的な床上の配分された所有権を、できるだけ連結し一 体的に利用可能なオープンな床を指向する。

ここには区分所有がもたらす二つの異なるべクトルが ある。一つは所有と利用の一致と分離である。所有と利 用の個別の分離自体はマンションの貢貸化にみるように どこでも成立するものである。しかし、この分離がオー プンな床利用を実現させるために、所有之直接の利用と の中間に組織的に介在させられるところに商業床の所有 と利用の分離の特色がある。さらに重要なのは第二のべ クトルである。それは所有及び利用の範囲の限定性之非 限定性である。マンションの区分が1住戸という完結性 を有する空間によって実体化されている意味において、 いくつもの区分を連結させて一体的に使うことは一般的 要求とはならない。二世帯住宅のように住戸が連続して も 1 住戸としての独立性は基本的には変わらない。それ に対し、商業系再開発ビルの床は 1 区分の所有の範囲を 越えて連続的一体的に利用することを指向している。一 般論として共有形式において指向されるべき空間形式を、 区分所有という所有領域の分割に基つく形式で実現しょ うとしている所に特徽がある。

所有および利用の範囲の非限定性という観点からみれ ば、その理念型として全体共有の建物がある。しかし、 区分所有は全体共有を回避するところに成立するのであ るから、全体之個、専有之共用の区別が何らかの形で存 在する。問題は区分を越えた一体的利用範囲としての非 限定領域をつくりだす形式である。それには、

(1)共有による専有部分の所有之利用

(2)無隔壁化を採用した空間的連続性の確保

(3)法定共用部分の活用

(4)規約共用部分の設定と活用

(5)二段階の貢貸借方式

がある。

商業系再開発ビルのマンションとのもう一つの違いは、 後者が各区分の独立した用途の集合的関係を一般的な管 理問題に限定するのに対し、前者は独立した区分相互間 の関係を重視し、管理およびそこに成立する各施設の経 営を共通の問題としているところにある。マンションに おいても居住という共通の機能に対しての共通認識と協 力を求められるが、それは利潤を追及する商業活動とは 異なる次元のものである。居住の快適さを実現する「生 活ルール」に対して、商業活動を円滑に行うための「経 営戦略と組織対応」がここでは求められる。この点と先 の区分床の連続的利用が結び付いて、現実の床のオープ ン利用が可能となり、また、一体的管理を可能としてい る。

ここで取り上げた二事例は、複雑な区分所有形式をと りながらオープンな林利用を実現している事例で、区分 
㦿の独立性を弱める様々な方法と区分床の共有的利用を 実現するシステムを含んだ事例といえる。すなわち、こ のケース・スタディは区分所有と空間的連続性の実現お よび共有的利用が両立不可能なものではなく、十分コン トロールされた管理システムのもとでの両立可能性を示 唆しているといえよう。

\section{謝辞}

本研究に対して平成 $3 \sim 4$ 年度文部省科学研究費補助 金（一般研究C課題番号03650483代表者 近江 隆）の 助成を受けた。また、資料の閲覧、ヒヤリング等、S市 関係部局、法務局、地権者法人、担当コンサルタント等 の方々のご協力を戴いた。記して感謝申し上げます。

注

1)坂和章平・中井康之・岡村承期 : 岐路に立つ都市再開発一升煐士からの実践 的プロボーザルー、都市文化社、1987.7

2)近正 隆・相原利至・真野和洋：再開発ビルにおける区分所有の成立形能
一仙台市と東京都において施行された 9 事業を事例として一、日本建築学会 計画采論文報告集＼cjkstart第453号、pp87 94、1993.11

3)同上

4）(社）全国市街地再開発協会：日本の都市再開発 2 -市街地再開発事業の全 記録一、1986.1

同 : 日本の都市再開発 3-市街地再開発事業の全記録一、1991. 6

A 地区市街地再開発組合、（株）S 駅前開発ビル：S市A 地区市街地再開発 事業、 1982.4

B地区市街地再開発組合：都市再開発一B 地区市街地再開発事業の記録一

同 : B 再開発事檏のあゆみ、1991. 3

他

5) 日本の都市再開発 2、3より

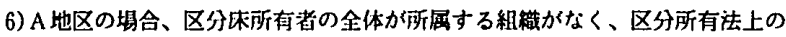
区分所有者の団体としての役割を果たす管理組合がない。そこで、区分所有 法上の管理者である地概者法人に以下の権限を与え、その役割を補っている。 （1）共用部分の保存、管理に関する一切の行為

(2)果会の決議、区分所有者の合意事項の実行。

(3)本規約に定めるほか、ビル管理に必要な一切の行為。

7) B 地区の場合、管理規約は都市再開発法第133条（建物の区分所有等に関す ろ法律の特例等）に基うく。区分所有者全目を組合目とする管理粗合を組械 し、区分所有法上の管理者として地権者法人がれれたたる。

8) A 地区の管理規約の中で定我された「共同使用部分」は、一般的に仕共同利 用と同義であり、この部分を引用する場合のみ、以下、「」で表現し ている。 